\title{
PERSEPSI GURU BAHASA INDONESIA TERHADAP PUISI LAMA GURINDAM
}

\author{
Sri Suhita \\ Universitas Negeri Jakarta \\ E-mail: srisuhita@unj.ac.id
}

\begin{abstract}
ABSTRAK
Tujuan penelitian ini untuk memperoleh gambaran tentang persepsi guru sekolah menengah terhadap gurindam sebagai sastra lama Indonesia bergenre puisi. Selain itu, juga untuk mengetahui implikasi pembelajarannya di sekolah. Penelitian ini menggunakan metode deskriptif kualitatif berjenis expost facto. Data diperoleh melalui kuesioner yang disebarkan kepada guru pengajar Bahasa Indonesia di sekolah menengah di wilayah Jakarta. Fokus penelitian ini ialah persepsi guru yang terefleksi berdasarkan kategori pengetahuan, apresiasi, dan praktikal. Penelitian ini menghasilkan data yang menunjukkan bahwa persepsi guru terhadap gurindam ternilai positif, didasari dengan tingginya pengetahuan dan kesediaan guru untuk tetap mengajarkan gurindam meskipun dalam Kurikulum 2103 tidak lagi secara eksplisit dituliskan seperti halnya pantun dan syair. Penelitian mengenai persepsi guru terhadap gurindam ini bermanfaat bagi pembelajaran dan pendidikan baik formal maupun nonformal, khususnya pada jenjang pendidikan menengah di Indonesia.
\end{abstract}

Kata kunci: persepsi guru, sastra lama, gurindam, Gurindam Dua Belas

\section{PERCEPTION OF INDONESIAN TEACHER ON OLD POETRY OF GURINDAM}

\begin{abstract}
The purpose of this research is to obtain a description of the perception of secondary school teachers to gurindam as the old Indonesian literary genre. In addition, also to know the implication of learning it on school. This research use descriptive qualitative method which type expost facto. Data were obtained through questionnaries distributed Indonesian language teachers in secondary school in Jakarta. The focus of this research is the perception of teachers reflected by categories of knowledge, appreciation, and practical. This research data showing that teachers perception of gurindam are positive, based on the high gurindam and willingness of teachers to keep teaching gurindam eventhough in the Curriculum 2013 no longer explicitly written as well as pantun and syair. Research on teacher perception of gurindam is useful for learning and education both formal and nonformal especially in secondary education in Indonesia.
\end{abstract}

Keywords: teachers perception, old literary, gurindam, Gurindam Dua Belas 


\section{PENDAHULUAN}

Dalam dunia sastra Indonesia dikenal adanya penggolongan berdasarkan waktu kemunculannya, sehingga terbentuk penggolongan sastra lama, sastra baru, dan atau sastra modern. Penggolongan ini dilandasi oleh dinamika sosial di saat kemunculannya. Sehingga dengan mengenali ciri produk sastra, kita dapat mengenali dinamika masyarakat pada zamannya. Substansi hahikat sastra dan nilai pesan yang terkandung dalam sastra tidak berubah. Sehingga, sastra sebagai bagian dari budaya yang terlimitasi sebagai hasil cipta, karya, dan karsa manusia yang indah dan bermanfaat tetap penting, perlu, dan relevan dengan pemanusiaan manusia ke arah manusiawi.

Pemerintah melalui Badan Pengembangan dan Pembinaan Bahasa pada tahun 2009 menerbitkan Undang-undang Republik Indonesia Nomor 24 Tahun 2009 tentang Bendera, Bahasa, Lambang Negara, dan Lagu Kebangsaan. Bab III Bahasa Negara Pasal 41 ayat 1 dinyatakan bahasa pemerintah wajib mengembangkan, membina, serta melindungi bahasa dan sastra Indonesia, agar tetap memenuhi kedudukan dan fungsinya dalam kehidupan bermasyarakat, berbangsa, dan bernegara sesuai dengan perkembangan zaman. Akan tetapi, implementasi undang-undang itu terganggu oleh penerapan Kurikulum 2013 dengan penekanan pengajaran yang berbasis teks. Sehingga tidak memiliki waktu dan dukungan yang cukup untuk menjalankan fungsi guru sebagai pendidik melalui pembelajaran sastra.

Undang-undang tersebut secara jelas dan tegas mengamanatkan kepada seluruh bangsa Indonesia, agar mengembangkan, membina, dan melindungi bahasa dan sastra Indonesia. Meskipun pasal 41 ayat (1) tidak menyebutkan secara eksplisit jenis sastra yang harus dibina, dilindungi, dan dikembangkan, namun gurindam sebagai bagian dari sastra lama juga patut mendapatkan perlakuan tersebut. Dengan demikian, secara 
kultural menganggap dan atau memosisikan gurindam pada tatanan dan tataran sekadar melengkapi jumlah dalam konteks pembelajaran dan pendidikan, merupakan bentuk pengingkaran legalitas dan sosiokultural. Hal ini sekaligus menutup celah fungsionalisasi pembelajaran gurindam sebagai alat pendidikan yang penting dan strategis. Hal ini diperjelas dengan kemunculan Kurikulan 2013 yang mengatus pangajaran dilaksanakan berbasis teks. Dalam Kurikulum 2013, pembelajaran sastra hanya berorientasi pada pengembangan aspek kognitif, dan meniadakan pengembangan aspek afektif.

Jika dikaitkan dengan era milenium yang sedang berproses secara dinamis saat ini, fungsionalisasi pembelajaran gurindam di sekolah menengah secara konseptual masih sangat penting dan relevan di tengah pengaruh budaya luar, baik dari sisi positif maupun negatifnya. Nilai penting pembelajaran sastra jenis gurindam, terletak pada esensi gurindam yang sarat dengan kemampuan gurindam mengintroduksi dan menginternalisasi nilai-nilai positif dan konstruktif kepada peserta didik. Sehingga, peserta didik akan merasakan kehalusan pengaruh baik ke dalam dirinya. Dengan kata lain, pembelajaran gurindam merupakan alat yang efektif guna membangun peserta didik dalam berproses menjadi manusia yang manusiawi.

Patut disayangkan apabila pembelajaran gurindam tersisih dari pembelajaran Bahasa Indonesia di sekolah menengah, karena berdasarkan kajian akademik yang dilakukan melalui penelitian-penelitian ilmiah oleh dosen, mahasiswa, dan lembaga yang berkiprah dalam kesusastraan, diperoleh fakta bahwa sastra lama jenis gurindam sarat dengan nilai keagamaan, sosial, dan budaya yang relevan didudukkan sebagai materi dan alat pendidikan yang substantif, dalam rangka membantu anak didik menumbuhkembangkan potensi kemanusiaan dalam dirinya sebagai makhluk Tuhan, 
individu, dan sosial. Dengan demikian, mengesampingkan atau meniadakan gurindam dalam pembelajaran sastra sama dengan menihilkan hak siswa dalam memperoleh materi, cara, dan kesempatan terbaik dalam upaya menumbuhkembangkan dirinya.

Apa penyebab ketersisihan itu? Apakah terbentuk persepsi negatif guru terhadap pembelajaran gurindam? Hal tersebut yang menjadi bahan kajian pada penelitian ini, dengan tujuan mencegah hilangnya gurindam dari pembelajaran di sekolah menengah. Selain itu, juga untuk mencari solusi agar guru tetap antusias mengajarkan materi sastra lama khususnya gurindam sebagai penyandang predikat profesional di bidang pengajaran dan pendidikan.

Gurindam secara sederhana memiliki arti sebuah puisi. Puisi memberikan gambaran pikiran dan perasaan yang berhubungan dengan realitas kehidupan (Lastari, 2017). Gurindam termasuk ke dalam genre puisi lama, yang banyak didapati pada kehidupan masyarakat Melayu Indonesia (Alisjahbana, 1985). Gurindam yang sangat terkenal di Indonesia ialah Gurindam Dua Belas, karya Raja Ali Haji (1808-1873) yang diselesaikannya pada tahun 1846. Beliau lahir di Pulau Penyengat, yang kini masuk dalam wilayah Kepulauan Riau.

Selain sebagai sastrawan yang dikenal produktif dan ulama, pada tahun 2004 Raja Ali Haji diakui sebagai salah satu Pahlawan Nasional Indonesia. Nama lengkap beliau yaitu Raja Ali al-Hajj ibni Raja Ahmad al-Hajj ibni Raja Haji Fisabilillah. Nama ini menjadi panjang, karena orang Melayu senang memberikan kepada anaknya nama kakek yang sudah meninggal. Raja Ali Haji merupakan putra Raja Ahmad dan Encik Hamidah binti Panglima Malik Selangor atau Putri Raja Selangor. Raja Ahmad pernah menuliskan karya-karya besar seperti Syair Perjalanan Engku Putri ke Lingga, Syair Perang Johor, dan Syair Raksi. 
Raja Ali Haji menciptakan gurindam sebagai bentuk mas kawin untuk Engku Puteri Hamidah, yang juga tinggal di Pulau Penyengat. Mas kawin dipahatkan di batu marmer sebagai bukti rasa cinta kepada istrinya. Gurindam karya Raja Ali Haji dinamakan Gurindam Dua Belas, sesuai dengan jumlah pasal yang terdapat pada gurindam tersebut. Gurindam Dua Belas berisi nasihat yang bersifat universal dan bernuansa keislaman (Sugianto, 2015). Keistimewaan lain dari gurindam tersebut ialah dari banyaknya pasal yang berjumlah 12 pasal (Sapto, 2012). Jumlah bait dalam tiap pasal minimal 5 bait. Bahkan hampir semua lariknya pada setiap bait, mengandung rima yang sama sesuai dengan ciri gurindam yang terbentuk dari satu kalimat majemuk, ditulis dalam dua larik berima sama.

Begitu pentingnya peran persepsi terhadap sesuatu, para ahli terus melakukan kajian guna menemukan bentuk dan format yang lebih benar dan tepat, sehingga memudahkan upaya manusia untuk mencapai tujuannya (Sobur, 2013). Persepsi didefinisikan sebagai penglihatan, bagaimana cara seseorang melihat sesuatu atau pandangan, atau pengertian, yaitu bagaimana seseorang memandang atau mengartikan sesuatu (Leavit, 1978). Dengan demikian, dapat dikatakan bawa persepsi mengandung arti cara seseorang memahami atau mengartikan sesuatu atau bagaimana seseorang melihat suatu objek.

Selanjutnya Pareek (1996) mendefinisikan persepsi adalah proses menerima, menyeleksi, mengorganisasikan, mengartikan, menguji, dan mereaksi kepada rangsangan pancaindra atau data. Persepsi juga berari proses pemahaman atau pemberian makna atas suatu infoemasi terhadap stimulus. Stimulus di dapat dari proses pengindraan terhadap objek, peristiwa, atau hubungan antargejala yang selanjutnya diproses oleh otak. Melalui persepsilah sebuah proses kognisi dimulai. 
Berdasarkan definisi di atas dapat dikatakan bahwa resepsi adalah respons psikologis terhadap rangsang dari luar yang tertangkap oleh pancaindra. Dengan demikian persepsi menentukan pemilihan suatu stimulus atau pesan dan mengabaikan pesan yang lain.

Ada tiga aspek dalam persepsi yang dianggap sangat relevan dengan kognisi manusia, yaitu pencatatan indra, pengenalan pola, dan perhatian. Persepsi mencakup dua proses yaitu bottom-up atau data driven processing (aspek stimulus) dan top-down atau conceptually driven processing (aspek pengetahuan seseorang). Hasil persepsi seseorang mengenai suatu objek, selain dipengaruhi oleh penampilan objek itu sendiri, juga dipengaruhi oleh pengetahuan seseorang mengenai objek tersebut. Faktor yang memengaruhi persepsi pada dasarnya dapat dibagi menjadi dua, yaitu: faktor internal dan faktor eksternal (Pareek, 1996).

1. Faktor internal yang memengaruhi persepsi yaitu faktor-faktor yang terdapat dalam diri individu, yang mencakup: (1) fisiologis, (2) perhatian, (3) minat, (4) kebutuhan yang searah, (5) pengalaman dan ingatan, serta (6) suasana hati.

\section{a. Fisiologis}

Informasi masuk melalui alat indra. Selanjutnya informasi yang diperoleh ini akan memengaruhi dan melengkapi usaha untuk memberikan arti terhadap lingkungan sekitarnya. Kapasitas indra untuk mempersepsi pada setiap orang berbeda-beda, sehingga interpretasi terhadap lingkungan juga dapat berbeda.

b. Perhatian

Individu memerlukan sejumlah energi yang dikeluarkan untuk memperhatikan atau memfokuskan diri pada bentuk fisik dan fasilitas mental yang ada pada suatu objek. 
Energi setiap orang berbeda-beda, sehingga perhatian seseorang terhadap objek tertentu juga berbeda. Hal ini akan memengaruhi persepsi terhadap suatu objek.

c. Minat

Persepsi terhadap suatu objek sangat bervariasi, bergantung pada seberapa banyak energi atau perceptual vigilance yang digerakkan untuk mempersepsi. Perceptual vigilance merupakan kecenderungan seseorang untuk memerhatikan tipe tertentu dari stimulus atau dapat dikatakan sebagai minat.

d. Kebutuhan yang searah

Faktor ini dapat dilihat dari bagaimana kuatnya seseorang atau individu mencari objek-objek atau pesan yang dapat memberikan jawaban sesuai dengan dirinya.

e. Pengalaman dan ingatan

Pengalaman dapat dikatakan bergantung pada ingatan, dalam arti sejauh mana seseorang dapat mengingat kejadian-kejadian lampau untuk mengetahui suatu rangsang dalam pengertian luas.

f. Suasana hati

Keadaan emosi memengaruhi perilaku seseorang. Suasana hati ini menunjukkan bagaimana perasaan seseorang pada waktu tertentu, yang dapat memengaruhi seseorang dalam menerima, beraksi, dan mengingat.

2. Faktor eksternal yang memengaruhi persepsi

Dalam konteks ini persepsi merupakan faktor yang sangat penting dalam membentuk sikap terhadap rangsangan dari luar. Sehingga dalam tatanan pembelajaran sastra lama khususnya gurindam, persepsi positif terhadap gurindam akan menentukan kualitas, produktivitas, serta efektivitas pembelajaran dan atau pendidikan, khususnya pendidikan kepribadian peserta didik. 
Berdasarkan beberapa definisi tentang persepsi tersebut, dapat disimpulkan bahwa persepsi merupakan unsur psikologis yang mendasari penyikapan seseorang terhadap objek dan kondisi tertentu yang ada di lingkungan seseorang. Persepsi yang dibentuk dan dimiliki oleh seseorang menentukan sikap seseorang, karena persepsi merupakan bagian dari keseluruhan proses yang menghasilkan tanggapan dan penyikapan. Sehingga, para ahli berpendapat bahwa sikap dan perilaku seseorang merupakan fungsionalisasi persepsi atau cara seseorang memandang sesuatu. Oleh karena itu, upaya memantapkan perilaku yang positif, fungsional, dan produktif dimulai dari upaya memantapkan dan memositifkan persepsi.

\section{METODE}

Metode penelitian yang digunakan dalam penelitian ini yaitu deskriptif kualitatif. Jenis data yang dipergunakan dalam penelitian ini ialah data kualitatif. Data kualitatif merupakan data nonangka yang bersifat deskriptif dalam bentuk informasi tulisan (kuesioner) yang diperoleh dari guru-guru Bahasa Indonesia di sekolah menengah, yang berkompeten memberikan informasi yang dibutuhkan dalam penelitian ini.

Sumber data yang digunakan terdiri atas data primer dan dara sekunder. Data primer, yaitu responden terpilih untuk memperoleh data secara langsung dari sumbernya, yaitu para guru pengajar Bahasa Indonesia di sekolah menengah Jakarta. Data tersebut diperoleh berdasarkan kuesioner yang disebarkan kepada responden yang menjadi sampel penelitian. Data sekunder, yaitu buku Puisi Lama karangan Sutan Takdir Alisjahbana, artikel ilmiah pendukung, dokumen Gurindam Dua Belas karya Raja Ali Haji, dan sumber referensi lainnya yang relevan dengan variabel penelitian. 


\section{HASIL DAN PEMBAHASAN}

\section{Gurindam dan Pembelajarannya di Sekolah}

Pembelajaran sastra di sekolah cenderung mengambil materi sastra modern, karena dunianya masih sezaman dengan para siswa. Sedikit demi sedikit sastra lama Indonesia mulai tergeser. Ketergesaran sastra lama patut diduga karena keengganan, atau bahkan karena ketidakmampuan para guru menangkap substasi nilai yang terkandung dalam memfungsikan aspek metodis sastra lama.

Pembelajaran sastra dalam materi ajar bahasa Indonesia mencapai puncaknya pada kurikulum KTSP, meskipun sebagian guru beranggapan bahwa porsi materi sastra masih sangat sedikit jika dibandingkan dengan materi kebahasaan. Pada saat kurikulum tersebut diterapkan, ada penilaian terbatas yang beranggapan bahwa kedua materi itu terbagi secara kurang adil. Beberapa guru dan sastrawan merancang pemisahan antara sastra dengan bahasa. Dengan demikian, diusulkan agar keduanya diajarkan oleh guru yang berbeda. Akan tetapi sampai berakhirnya penerapan kurikulum KTSP, usulan tersebut tidak pernah terealisasi.

Pergantian kurikulum menjadi Kurikulum 2013 atau dikenal juga dengan nama K-13, menempatkan bahasa Indonesia sebagai penghela ilmu pengetahuan. Dengan demikian bahasa Indonesia menempati kedudukan sebagai sarana berpikir, sedangkan sastra hanya bersifat tekstual. Untuk dapat mendukung struktur berpikir siswa, maka pembelajaran bahasa termasuk sastra disajikan berbasis teks.

Dasar pemikiran yang digunakan dalam pembelajaran sastra berbasis teks ialah penyamaan aspek metodis pengajaran bahasa. Dengan demikian, pengajaran sastra seperti ini mengeliminasi dan meniadakan substansi serta fungsi nilai sebagai unsur pembentuk dan pengembang nilai kemanusiaan. 
Mempelajari genre sastra atau penceritaan, harus memperhatikan jenis teks dan mengikuti uraian struktur teksnya. Padahal sastra nonnaratif jenis teks puisi termasuk gurindam, tidak memiliki struktur teks. Pada akhirnya para guru mengajarkan gurindam mengikuti pola lama atau sekadar membacakan contoh yang tertuang di buku pegangan guru dan buku pegangan siswa. Sehingga seolah gurindam hanya sebagai pelengkap yang mulai kehilangan fungsinya.

Hal ini terlihat pada sebagian guru yang beranggapan bahwa eksistensi gurindam tidak penting diajarkan, karena kurang relevan dengan perkembangan zaman dan secara praktis karena tuntutan dan tuntunan Kurikulum 2013. Gurindam memang termasuk sastra lama, namun apakah karena hal itu maka gurindam tidak mendapatkan tempat yang penting dan proporsional dalam pembelajaran bahasa dan sastra Indonesia? Gurindam bukan saja berada pada tempat yang penting, namun gurindam juga berfungsi penting dalam membangun kepribadian bangsa di tengah-tengah kehidupan yang semakin hedonis dan pragmatis, yang berujung pada dekadensi moral dan sosiabilitas.

Berkat Gurindam Dua Belas karya Raja Ali Haji, nama Indonesia dikenal sampai ke mancanegara dan semakin menyeruak ke kancah peradaban dunia. Sebagai sebuah karya sastra lama gurindam memiliki beberapa keistimewaan antara lain mengandung nilai-nilai pembangun karakter bangsa, karena ciri khas gurindam berisi nasihat atau petuah, pelajaran, dan falsafah hidup. Kandungan nilai religiusitas, moralitas, dan sosialitas dalam gurindam sesungguhnya merupakan modalitas yang berharga, penting, dan relevan untuk memfungsikan sekolah sebagai instrumen pendidik dan pengajar sebagai pendidik anak bangsa.

Dalam praktik keseharian manusia, keterlibatan dan dialektika dalam konteks relasional dengan sastra, niscara bersinggungan dengan substansi gurindam sebagai 
bagian dari jenis sastra lama Indonesia. Walaupun dalam kenyataannya, gurindam kurang menyeruak ke permukaan dinamika kehidupan manusia, dibandingkan dengan pantun yang juga bagian dari jenis puisi lama. Demikian juga dalam tataran pembelajaran di sekolah menengah, gurindam mulai kurang difungsikan sebagai salah satu alat pendidikan. Pada kenyataannya gurindam pada umumnya dan Gurindam Dua Belas karya Raja Ali Haji berisi nilai keagamaan, kemanusiaan dan atau sosiokultural yang sangat penting dan bermanfaat bagi kehidupan manusia. Berikut ini dikutip contoh pasal yang pertama dari Gurindam Dua Belas karya Raja Ali Haji.

\section{GURINDAM DUA BELAS}

$$
\text { Raja Ali Haji }
$$

Ini gurindam pasal yang pertama:

Barang siapa tidak memegang agama, sekali-kali tiada boleh dibilangkan nama.

Barang siapa mengenal yang empat maka ia itulah orang yang ma' rifat.

Barang siapa mengenal Allah, suruh dan tegahnya tiada ia menyalah.

Barang siapa mengenal diri, maka telah mengenal akan Tuhan yang bahri.

Barang siapa mengenal dunia, tahulah ia barang yang teperdaya.

Barang siapa mengenal akhirat, tahulah ia dunia mudarat.

Sebagai bentuk sastra lama, kata-kata dalam Gurindam Dua Belas banyak menggunakan bahasa Melayu-Indonesia. Untuk memperjelas arti kata yang dianggap sulit karena tidak lagi sezaman, dalam buku Puisi Lama diberi arti pada beberapa kata yang dianggap sulit tersebut. 


\section{Persepsi Guru terhadap Pembelajaran Puisi Lama}

Dalam praktik keseharian manusia, keterlibatan dan dialektika dalam konteks relasional dengan sastra, niscara bersinggungan dengan gurindam sebagai bagian dari jenis sastra lama Indonesia. Walaupun dalam kenyataannya, gurindam kurang menyeruak ke permukaan dinamika kehidupan manusia, dibandingkan dengan pantun dan syair yang juga merupakan bagian dari jenis puisi lama. Demikian juga dalam tataran pembelajaran di sekolah menengah, gurindam mulai kurang difungsikan sebagai salah satu alat pendidikan.

Berbahasa dan bersastra pada dasarnya merupakan aktivitas yang khas pada diri manusia. Sastra bahkan dapat dikatakan sebagai duplikasi kehidupan bagi manusia. Sehingga muatan sastra sesungguhnya merupakan permasalahan manusia dengan berbagai aspek kemanusiaan itu sendiri. Dengan demikian, membincangkan manusia berarti membincangkan sastra, demikian pula sebaliknya.

Terkait dengan manusia, khususnya sastra, fungsionalisasi produktifnya sangat bergantung pada persepsi manusia yang berada di dalam dan di antara wujud sastra tersebut. Persepsi seseorang sangat penting dan strategis, dalam memberikan jaminan kepada bentukan manusia yang manusiawi dan bermartabat. Sebuah realitas umum, jika persepsi seseorang terhadap sesuatu yang baik, indah, dan berguna akan berkorelasi positif dengan sikap dan perilaku seseorang terhadap perlakuan, pemfungsikan, pelestarian, pemertahanan, dan penumbuhkembangan sesuatu tersebut. Dengan kata lain, persepsi yang positif terhadap karya sastra, berdampak positif pula terhadap penyikapan seseorang. Semakin positif persepsi seseorang terhadap kesusastraan Indonesia khususnya karya sastra, semakin positif pula penyikapannya. 
Dengan demikian dapat dikatakan bahwa persepsi sangat penting dalam menyikapi pembelajaran sastra khususnya gurindam. Penyikapan yang diawali dengan persepsi positif terhadap gurindam dan pembelajarannya, bernilai penting dan strategis dalam upaya menumbuhkembangkan kepribadian peserta didik. Bagi guru berpotensi menumbuhkembangkan semangat dan kepuasan dalam mengajarkannya. Selain itu, faktor kreativitas guru akan terpengaruh dan terpacu untuk berkembang.

Produktivitas, fungsionalitas, dan efektivitas pengajaran dan atau pendidikan sesungguhnya harus dilakukan secara komprehensif. Komprehensivitas tersebut meliputi ketuntasan aspek ontologis, epistemologis, dan aksiologis. Jika dari ketiga aspek tersebut hanya difungsikan sebagiannya saja, patut diduga efektivitas pembelajaran akan rendah bahkan tidak tercapai. Aspek persepsi seseorang dalam konstelasi pengajaran meliputi ketiganya, yaitu tentang ke-apaan, ke-bagaimanaan, dan ke-untukapaan. Kesiapan dan kemantapan persepsi yang hanya meliputi aspek ontologis, akan menjauhkan aspek trategi dan tujuan pembelajaran karena pengajar hanya mengetahui sebuah konsep saja. Sementara cara, strategi, arah, serta tujuan pengajaran menjadi bagian yang terlepas dan terpisahkan.

Seorang guru pengajar sastra diprediksi tidak akan berhasil mencapai tujuan pembelajaran, jika guru hanya mengetahui, mengerti, dan memahami konsep gurindam secara definitif, namun mengabaikan aspek latar belakang, proses terbentuknya, dan tujuan keberadaan gurindam. Oleh sebab itu, persepsi yang komprehensif tentang sastra (gurindam) yang meliputi ontologis, epistemologis, dan aksiologis konsep sastra (gurindam), merupakan faktor yang mendeterminasi efektivitas pengajaran, khususnya pengajaran materi gurindam. Komprehensivitas pengetahuan dan pemahaman materi ajar merupakan konsekuensi logis tugas profesional seorang guru atau pengajar dalam 
kiprahnya sebagai manusia beradab yang memilih tugas profesional sebagai guru, yang mengadabkan manusia atau memanusiakan manusia.

Sehubungan dengan persepsi yang merupakan modalitas efektivitas mengajar, kemampuan mempersepsi suatu rangsang spesifik sangat diperlukan oleh setiap orang. Guru pada khususnya harus memastikan dirinya bahwa persepsinya tentang materi ajar atau bahan ajar yang akan ditransformasikan kepada peserta didik, benar-benar telah cukup dan benar. Kecukupan dan kebenaran persepsinya harus sudah mencakupi aspek ontologis, epistemologis, dan aksiologis tentang bahan ajar tersebut. Dalam tataran ini faktor penjamin efektivitas pengajarannya yang perlu dikonfirmasikan ialah para pengajar tersebut sudah menguasai dan mahir menerapkan aspek metodiknya. Karena betapa pun seorang guru memiliki persepsi positif terhadap materi ajar jika aspek metodiknya lemah, efektivitas mengajarnya berpotensi rendah.

Walaupun persepsi sangat penting dan strategis dalam konteks mengajar agar efektif, persepsi bukan segalanya atau bukan unsur penentu efektivitas pengajaran yang mutlak dan monopolistis. Persepsi bersifat kompleks karena kebulatan persepsi dipengaruhi oleh penghayatan. Sesuatu yang kita hayati tidak hanya bergantung pada rangsang saja, tetapi bergantung pada proses kognitif yang merefleksikan minat, kecenderungan, harapan, dan pertimbangan saat itu.

Pada hakikatnya gurindam merupakan bagian dari sastra lama Indonesia bergenre puisi, yang sarat dengan nilai dan pesan moral berbasis tradisi. Di dalam masyarakat tradisional lama, pendidikan dilakukan diantaranya dengan menyampaikan nasihat atau petuah kepada putra-putri dan keluarga mereka. Salah satu bentuk penyampaian kalimat nasihat tersebut menggunakan kalimat majemuk dengan dua larik 
bersajak sama yang dinamai gurindam. Dengan demikian, dapat dikatakan bahwa gurindam merupakan alat sekaligus materi pendidikan.

Gurindam Dua Belas merupakan karya sastra berbentuk puisi didaktis, karena kandungan di dalamnya berupa nasihat dan tuntunan hidup yang berbasis religiusitas. Penyampaian nilai-nilai moral dan keagamaan dalam bentuk satu kalimat majemuk yang singkat, mengandung nilai ketuhanan, nilai kemanusiaan, dan sarat makna, menjadi ciri sebuah gurindam.

Contoh:

Dengan bapa jangan durhaka, supaya Allah tiada muka.

Dengan ibu hendaklah hormat, supaya badan dapat selamat.

Kutipan ini diambil dari Gurindam Dua Belas karya Raja Ali Haji dari pasal kesepuluh bait 1 dan 2 .

Dengan demikian gurindam bukan saja penting, namun strategis sebagai materi dan alat pendidikan yang memiliki kekuatan dalam upaya memanusiawikan manusia. Oleh karena nila ketuhanan dan nilai kemanusiaan akan selalu melekat dalam kehidupan manusia, maka gurindam secara substansi tetap penting dan relevan dengan kehidupan manusia. Lebih-lebih sejak beberapa tahun yang lalu nilai-nilai keagamaan dan kemanusiaan semakin menipis, sehingga orientasi hidup manusia semakin individualistis dan hedonis. Dengan kata lain, sosiabilitas masyarakat semakin mengarah ke hubungan antar dan intramanusia yang bersifat transaksional.

Gurindam yang telah terbukti dan teruji keberadaan serta fungsinya ialah Gurindam Dua Belas karya Raja Ali Haji. Ciri khas gurindam yang mudah dikenali 
sekaligus memiliki kekuatan didaktis dan motodis yaitu kalimat pada gurindam sangat hemat. Antara larik pertama dan kedua sesungguhnya hanya merupakan satu kalimat majemuk. Selain itu, kecondongan isi pesan atau nasihat sudah dapat dideteksi pada induk kalimat.

Data penelitian tentang gurindam ini didudukkan dalam konteks pengajaran dan atau pendidikan berupa profil persepsi guru tentang gurindam sebagai modalitas strategis pembelajaran bahasa Indonesia dan sebagai alat pendidikan moral keagamaan di sekolah menengah. Data penelitian yang didapat melalui kuesioner lebih banyak menekankan pada cara guru mempersepsi dan mengimplementasikan gurindam dalam proses belajar mengajar dalam konteks proses belajar mengajar di sekolah. Responsi terhadap butir-butir kuesioner pada umumnya berupa respons yang spontan dan komprehensif. Sehingga data yang diperoleh dapat diorganisasikan secara lengkap, terstruktur, serta akuntabel sebagai representasi kualitas guru pengampu mata pelajaran Bahasa Indonesia, khususnya sastra lama berjenis gurindam.

Secara keseluruhan respons subjek penelitian dikelompokkan ke dalam 3 kategori, yaitu: pengetahuan, apresiasi, dan praktikal. Komposisi persentase ke-3 kategori tersebut yaitu pengetahuan sebanyak $33 \%$, kategori apresiasi sebanyak $40 \%$, dan kategori praktikal sebanyak $27 \%$. Keseluruhannya dimaksudkan untuk melacak tingkat pengetahuan, apresiasi, dan praktikal guru tentang sastra lama gurindam.

Butir-butir kuesioner yang diajukan kepada responden, secara strutur keseluruhannya merepresentasikan masing-masing kategori. Pada kategori pengetahuan, titik berat pelacakan pada upaya memperoleh jawaban tentang pengertian, pengetahuan, relevansi gurindam, dan pengetahuan serta pemahaman tentang Gurindam Dua Belas sebagai materi ajar pokok sastra lama gurindam. Pada kategori apresiasi, pelacakan 
dititikberatkan pada minat dan upaya menciptakan situasi proses belajar mengajar, konsistensi referensial, upaya memperoleh referensi, kemanfaatan, dan variasi pembelajarannya. Pada kategori praktikal titik berat pelacakannya pada keinginan untuk mengajarkan, kepentingan pengajaran, serta ketertarikan guru dan siswa terhadap pembelajaran gurindam.

Berdasarkan respons subjek penelitian, diperoleh data yang cukup signifikan. Rata-rata persentase terhadap ketiga kategori tersebut sebesar 77,5 \%. Berarti pengetahuan, apresiasi, dan praktikal sebagai bentuk kesiapan mengajar puisi lama gurindam di sekolah menengah cukup tinggi, meskipun pengajarannya terkendala oleh aspek kurikulum.

\section{KESIMPULAN}

Kesimpulan penelitian ini yaitu persepsi guru terhadap gurindam ternilai positif, didasari dengan tingginya pengetahuan dan kesediaan guru untuk tetap mengajarkan gurindam meskipun dalam Kurikulum 2103 tidak lagi secara eksplisit dituliskan seperti halnya pantun dan syair. Penelitian mengenai persepsi guru terhadap gurindam ini bermanfaat bagi pembelajaran dan pendidikan baik formal maupun nonformal, khususnya pada jenjang pendidikan menengah di Indonesia.

\section{UCAPAN TERIMA KASIH}

Puji syukur ke hadirat Tuhan Yang Mahakuasa sehingga artikel ini dapat diselesaikan. Ucapan terima kasih kepada para guru sekolah menengah di Jakarta, yang dengan suka rela memberikan jawaban atas kuesioner yang dibagikan untuk melihat persepsi para guru tentang gurindam. 


\section{DAFTAR PUSTAKA}

Alisjahbana, S. T. (1985). Puisi lama. Jakarta: Dian Rakyat.

Badan Pengembangan dan Pembinaan Bahasa. 2011. Undang-undang Republik Indonesia nomor 24 Tahun 2009 tentang bendera, bahasa, dan lambang negara, serta lagu kebangsaan. Jakarta: Kementerian dan Kebudayaan.

Lastari, A. (2017). Pandangan dunia pengarang alam kumpulan puisi Blues untuk Bonnie karya Rendra (kajian strukturalisme genetik). Aksis: Jurnal Pendidikan Bahasa dan Sastra Indonesia. 1(1). 63-79. doi: doi.org/10.21009/AKSIS.010104

Leavit, H. J. (1978). Managerial psychology. Edisi keempat. Chicago: The University of Chicago.

Pareek, U. (1996). Perilaku organisasi. Jakarta: Pustaka Binaman Pressindo.

Sapto. (2012). Gurindam dua belas. Bandung: Kiblat Buku Utama.

Sobur, A. (2013). Psikologi umum, dalam lintasan sejarah. Bandung: Pustaka Setia.

Sugianto, E. (2015). Mengenal sastra lama; jenis, definisi, ciri, sejarah, dan contoh. Yogyakarta: Andi Offset. 